\title{
Explaining Intensity of Trade Integration and Tax Policies Towards ASEAN Economic Integration in an Era of Global Competitiveness
}

\author{
Saimul $^{1}$, Arif Darmawan ${ }^{2}$, Resha Moniyana Putri ${ }^{3}$ \\ \{sai_mul@yahoo.com ${ }^{1}$, arif.darmawan@feb.unila.ac.id ${ }^{2}$, reshaatina@gmail.com ${ }^{3}$ \} \\ Department of Economics Development, Faculty of Economics and Business, University of \\ Lampung, Lampung, Indonesia ${ }^{1,2.3}$
}

\begin{abstract}
The ASEAN Economic Integration guide free flow of services, investment capital, goods, and skilled labor in the region. Highlighting the importance of enhancing intra-regional trade, ASEAN member countries need to diversify several potential sectors within regional offers. Moreover, tax policies among member countries may have contributed to the business cycle and reflect regional integration burdens. This paper ambitions is to address and find a correlation between the intensity of economic/trade integration, tax policies, and business cycle in the form of ASEAN Economic Integration. This paper apply data of real GDP, exchange exports and imports, percentage of tax of GDP, and total trade from five sample ASEAN member countries. The intensity of trade volume with the scheme of economic integration and tax policy changes directly bring impact for business actors. Bringing prosperity and new opportunity for growth engine to the region, the challenge remains to ensure the growth is most-likely inclusive.
\end{abstract}

Keywords: ASEAN, Economic Integration, Intra-Regional Trade, Tariffs, Tax Policies.

\section{Introduction}

The mutual benefit between trade integration and business cycle has been a subject of renewed interest among international economists [1]. Trade integration on the business cycle also remains a crucial issue for the member countries in the regional cooperation network. The proliferation of various local integration initiatives, such as free trade agreements and investment treaties, has impelled economists to reconsider these initiatives' implications for the trade and business cycle relations among countries entering into these agreements.

In current public discussion on international trade, the center of attention has been focusing on discussion about trade integration affects the business cycle [2]. Based on current responding, trade integration and business cycle has positive correlation vice versa. Moreover, if the demand side is the main driven for business cycle in the region, the expectation of trade integration is to strengthen the impulse that might be occur. The total amount (that mostly economist figure out to calculate) is theoretically biased and arise more questions that might be harder to answered statistically. However, the differentiation in absolute comparative advantages and specialization patterns among countries advice that the correlation caused by trade integration on cyclical business susbstantially depend on which products that mostly the countries produced [3].

In the Asia region, encompassing Southeast Asia economies within the region, shaping the economical and political attention about trade integration which deliver disctintion between 
market-led and policy-led trade integration [4]. The critical highlights priorities in this region are to address the challenges and opportunities in terms of strengthening regional cooperation mechanisms.

Taking into account, the progress of the Association of Southeast Asian Nation (ASEAN) formation sounds a dynamic and diverse region. For sure, the region enjoy very good economic growth by by fostering foreign direct investment and trade sectors. Besides, ASEAN's ten member countries aim to jointly realize the development of competition policy and introduce deeper investment policies and dispute resolution system. This result expects to have growing economic opportunities by predominantly promoting trade and investment as well as strengthening ASEAN's global leading role as an economic epicenter.

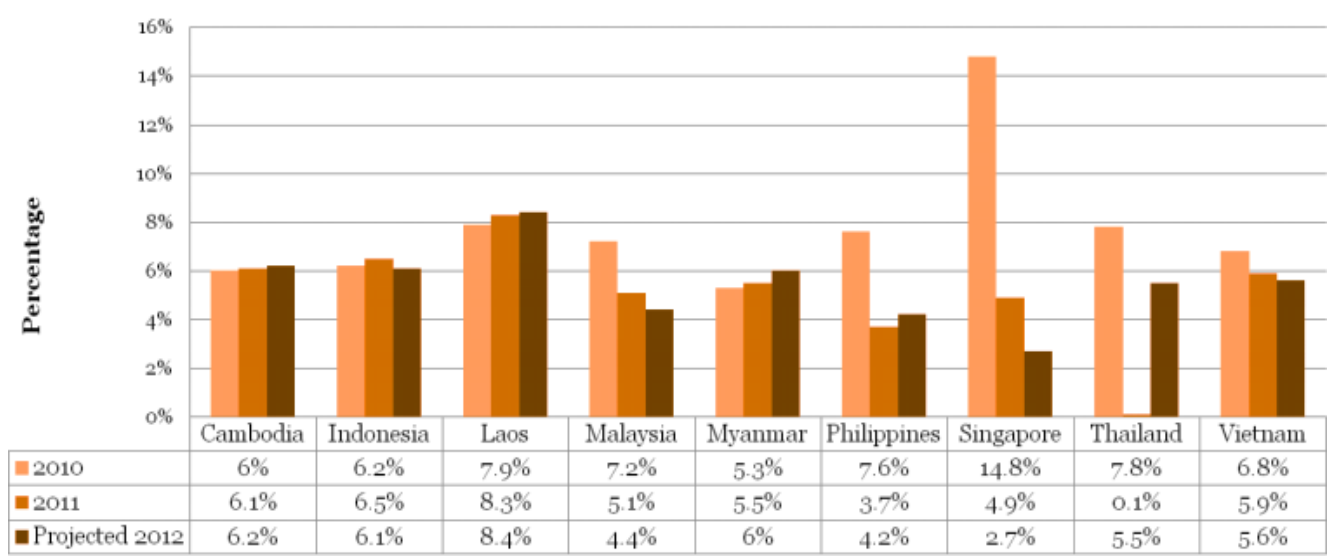

Fig 1. GDP Growth among the Nine-Member Countries of ASEAN (Source: PwC, 2012).

Incentives for tax reduction between ASEAN countries also another factor that change the competition which lead to avid attraction for FDI, global business' integration and regional development. In the globalization era, international companies emerge for need to find basecamp (center of production) with cheap labor, rich natural resources and developed technology. One country that lowering the tax rate on capital mostly ignores the resulting fall in income tax from other countries. The opposite of fiscal constraint arise from competition among countries to attract 'hot money' as known for low rates incentives, tax revenue reduction, underprovision of public goods, and lower welfare.

However, ASEAN is pursuing a policy to promote more significant intra-regional trade, and the adoption of the AFTA and several other integration policies will change the flows of trade and investment in the region. To create an internal market, ASEAN needs to be aware of its implications on their national taxation policies. Furthermore, using the PGC measures, ASEAN growth cycles are related to CLMV export cycles with a correlation coefficient of 0.6. The 13 ASEAN-5 and CLMV are increasingly interconnected so that booms and busts in ASEAN-5 can generate spillover effects to neighboring countries' exports.

This studies mostly similar with previous research on regional trade integration and business cycle analysis. First paper to examine the significant connection between regional trade integration and business cycle in Southeast Asia [5]. In Thornton and Goglio's model, the bilateral trade intensity has a significant connection with bilateral cross-country activities. Indeed, we added tax policies through a percentage tax of GDP variable. Different approach for globalization assume that produce policy outcome (as being too opposite for normative rule in the selected countries [6]. 
This paper extends Thornton and Goglio's work by developing a richer variables by adding a tax policy as intermediate variables which captures fiscal space on developing economies' features. Moreiver, it also expands some explanation [7] that concludes intensity of trade volume between developing and developed countries lead to result in more harmonized business cycles. By then, it slightly being a normative aspect which comes vary on different income level, productivity, and economic structures for other coutries outside emerging markets [8].

\section{Literature Review}

The theoretical relationship among trade integration, tax policies on corporate, and business cycle arise more biased view. Other economist, Heckscher-Ohlin concerns about trade that happened when two countries with different advantages, leading to specialize their factor production based on comparative and uniqueness as well as cross-country business cycle correlation. Furthermore, it also insults that trade can established for gap of industrial movement because of economic of scale, scarcity and consumers' preference for different product they desired, which means trade integration comes [9]. Long story short, it also mentioned about economic of scale can push agglomeration and concentration of production which bring negative impact on business cycle correlation [9]. However, Krugman did not specifically mentioned about vertical fragmentation of trade. They argue that an increasing production or we called as vertical fragmentation of trade can deliver to a high concentration of correlation of business cycle [10]. In the more empirical literature, it implies that, from ten industrial countries' data, increasing trade volume can have positive relation with business cycle [2], [7].

Several empirical studies agree for positive negation between trade integration and business cycles, and this phenomenon does not necessarily lead to business cycle (harmonization). Furhermore, some cases can come from the ground that bilateral agreement determine intensity of business cycle. They prove that differentiation in patterns bring negative impact between bilateral trade frequency and business correlation. In contrast, trade integration can give positive impact on business cycle [11]. Moreover, another researcher mentioned that sectorial concentration among the countries bring positive impact on business cycle [12]. They all make conclusion that increasing trade integration increases business cycle trade volume in Southeast Asia region and other Asian countries.

More recent studies elaborate on the impact of trade integration with tax policy in various regions. Using the tax rates on GDP, we can control for endogeneity concerns using instrumental variables. By and large, tax policy is a- cyclical in industrial countries but pro-cyclical in developing countries [13]. Further, their study's consistent tax policy model has related to the higher output volatility on the business cycle.

These update studies conclude for one meaning that the effect of increasing frequenct of trade in more than two countries on business cycle is very dependent not only the links but also on the transformation structural. The contribution of this studies is to investigate the earlier findings especially in the Southeast Asia region. It might be recorded that the trade is increase for several years is the leader the ASEAN member countries to closed the gap with economic integration and creating better opportunities for policy recommendation and trade integration. 


\section{Methodology and Data Analysis}

Measuring output comovements, annual data on GDP growth was collected for the ASEAN-5 (Indonesia, Malaysia, Thailand, The Philippines, and Singapore) member countries over 1996-2019 from World Bank Dataset. The period after 1997 is excluded for all variables because the Asian crisis distorts data and, by including it, the conventional measure of the business cycle could be exaggerated. Specifically, trade integration in ASEAN-5 dignified using the traditional composite index. The indexes coming from all industries and services for the period of 1996-2019 from the World Bank Dataset.

In the first stage, we follow several models that will be tested. For example, model first put in will be estimated [2]:

$$
\operatorname{Corr}(Q i, Q j)=\alpha+\beta I T i j+\varepsilon
$$

where Corr(Qi, Qj) stands for the correlation of de-trended real GDP, and ITij denotes the percentage of an intra-industry index between ASEAN-5 countries $i$ and $j$ in each period, and $\varepsilon$ is the error term.

Trade integration, based on the traditional trade theory, openness to trade should making bigger opportunities for specialization among the members. On the other hand, the biased of the idea is the impact of trade integration on the business cycle essentially an undeniable question. Indeed, even fixing with time series regression and simultaneous equation approached essentially finding a significant impact and most updated panel regression work controlling for country-pair fixed effects [14].

The theory says that trade is an important vehicle to boost economic linkages between countries in the region. However, theoretically, there is no consensus on whether increased trade intensity leads to more or fewer countries' business cycles. We added total trade to GDP (trade volume data) from 1990-2013 using World Bank Dataset. Thus, after adding all variables, we run a data panel regression to estimate coefficients of the following equation and test the impact of trade integration and tax policies on the business cycle which showing in the following equation below:

$y r(i, j, T)=\alpha \ln G D P(i, j)+\beta \ln T I(i, j, T)+\gamma \ln J P(i, j, T)+\delta \ln T(i, j, T)+\varepsilon(i, j, T)(2)$

where $y r(i, j, T)$ refers to the correlation of output between country I and country $\mathrm{j}$ during period T. For bilateral exports and imports, three measures are used: wx, wm, and wt. For the percentage of tax to GDP, using $J(i, j, T)$ and total trade derived from raw data without calculation.

\section{Finding and Discussion}

The ASEAN-5 member countries were chosen for this study since they have a relatively similar institution, standard levels of infrastructures, diversified industries, and represent Southeast Asia. Also, the data panel to find relations among significant business variables cycle processes, are easily identified in Asian countries [14]. Therefore, parties' policy preferences and the consequences of policy actions on business cycles are conceivably linked. 
The first that we used is compared the correlation of GDP growth rates of the five ASEAN economies with aggregate model for the group as a unity for the periods 1996-2007 and 20082019 to see the degree of the business cycle from one period to the next period. Furthermore, several variables that already mentioned above is bring another dimension to take a closer look for regional trade integration in the region. Despite of some obstacle, we can estimate and provide on the graph that shown below:
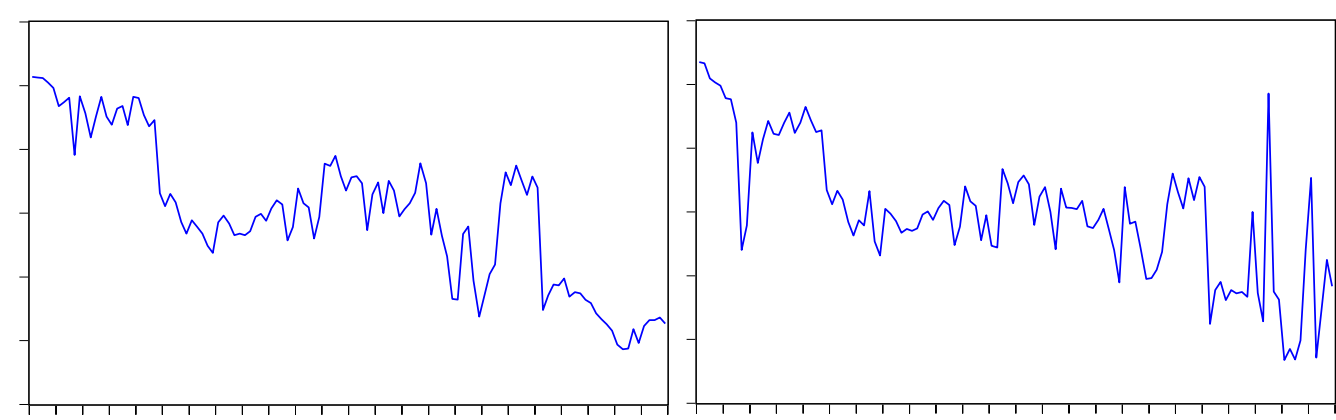

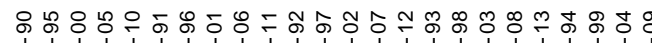

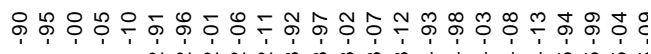
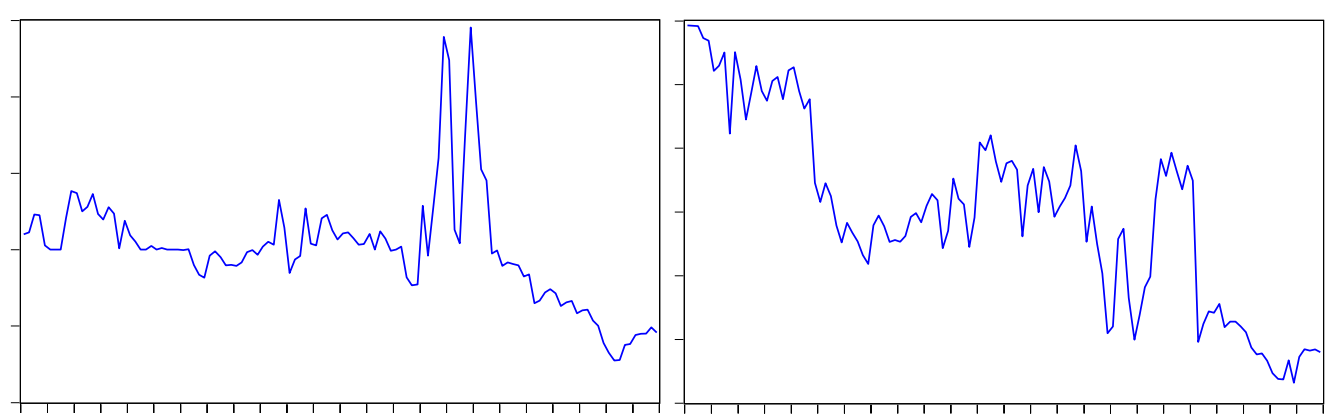

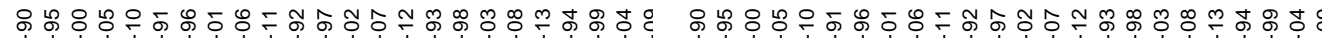

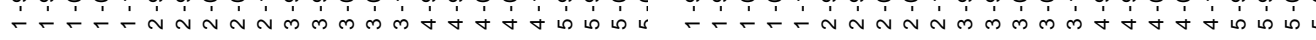

Fig 2. Correlation of GDP Growth, Trade Integration, and Percentage of Taxes

While the analysis in the time dimension is a standard tool of business cycle analysis, the spectral analysis application may offer new and more robust insight. Business cycles analysis is usually sensitive to the choice of de-trending techniques [15], [16]. Such countries may also display dynamic periods of high and low business cycle synchronization, commonly observed from the following graphs above.

\section{Conclusion}

The long journey ASEAN began with the adoption of the ASEAN Economic Integration. Nonetheless, progress has been made on many fronts, and the benefits from these advances have been far-reaching. We considered the relationship between trade integration and the cross- 
country correlation of business cycle activity in Southeast Asia (in this case, represented by ASEAN-5). Based on the result and findings, there is a positive and significant relationshop between thre degree of bilateral trade intensity and cross-country correlation of agreement and trade from the period 1996-2019, a period when trade integration was introduced in the Southeast Asia region.

By then, increasing trade volume among ASEAN member countries bring increasing higher degree of economic integration and volume within the region. Furthermore, a country's business cycle is expected to be continuously influenced by other economies in Southeast Asia, especially as trade within the region grows relatively more important than any sectors. So, we found that every 1 percent increase in exchange will positively impact GDP and tax shares on GDP.

Finally, we show that the member countries in Southeast Asia engaged intensively with trade integration, and the tax of GDP tends to impact business cycles within the region positively. At the same time, GDP will follow the excellent response of the intensity of trade integration. Although these results are somewhat subject to data problems, our results confirm the business cycle will influence the intensity of trade integration and tax policies among member countries in Southeast Asia.

\section{References}

[1] D. R. Hidayatullah, A. Darmawan, and S. Kallidumban, "Finding the strategy after corona crisis: the new normal and resilient economy growth in indonesia," vol. 3, no. 1, pp. 64-79, 2020.

[2] A. Saiki, "Business Cycle Synchronization and Vertical Trade Integration: A Case Study of the Eurozone and East Asia," Glob. Econ. J., vol. 18, no. 1, pp. 1-15, 2018, doi: 10.1515/gej-2017-0101.

[3] G. H. Y. Lee and M. Azali, "The endogeneity of the Optimum Currency Area criteria in East Asia," Econ. Model., vol. 27, no. 1, pp. 165-170, 2010, doi: 10.1016/j.econmod.2009.08.004.

[4] G. Lamont, "South East Asian Investment Opoortunities Tax \& Other Incentives," Pricewaterhouse Coopers (PWC), 2012.

[5] C. H. H. W. Hiteman, "International Business Cycles : World, Region, and CountrySpecific Factors," 1996.

[6] A. Darmawan and V. Faldi, "Unleashing the Potential of Globalization to Bring Sustainable Prosperity in the Selected Asian and African Countries: Panel LeastSquares Analysis," TEST Eng. Manag., vol. 82, pp. 6886-6897, 2020, [Online]. Available: http://www.testmagzine.biz/index.php/testmagzine/article/view/1955.

[7] J. Frankel, "On the rand: Determinants of the South African exchange rate," South African J. Econ., vol. 75, no. 3, pp. 425-441, 2007, doi: 10.1111/j.18136982.2007.00130.x.

[8] A. Saimul; Darmawan, "Understanding Causality Relation among FDI, Foreign Trade and Economic Growth,” EDAJ Econ. Dev. Anal. J., vol. 9, no. 4, pp. 414-426, 2020, [Online]. Available: https://journal.unnes.ac.id/sju/index.php/edaj/article/view/39044.

[9] R. Baldwin and P. Krugman, "Agglomeration, integration and tax harmonization," Eur. Bus. Rev., vol. 13, no. 3, pp. 18-19, 2001, doi: 10.1108/ebr.2001.05413cab.010.

[10] M. A. Kose and K. M. Yi, "International trade and business cycles: Is vertical specialization the missing link?," Am. Econ. Rev., vol. 91, no. 2, pp. 371-375, 2001, doi: 10.1257/aer.91.2.371

[11] C. Calderón and L. Servén, "WPS3400 The Effects of Infrastructure Development on 
Growth and Income Distribution," 1818.

[12] K. U. Leuven, "Centre for Transition Economics," Transition, vol. 32, no. 0, pp. 1-38, 2000.

[13] D. Kohli, R. Sliuzas, and A. Stein, "Urban slum detection using texture and spatial metrics derived from satellite imagery," J. Spat. Sci., vol. 61, no. 2, pp. 405-426, 2016, doi: 10.1080/14498596.2016.1138247.

[14] K. Shin and Y. Wang, "Trade integration and business cycle co-movements: The case of Korea with other Asian countries," Japan World Econ., vol. 16, no. 2, pp. 213-230, 2004, doi: 10.1016/S0922-1425(03)00028-8.

[15] P. Antràs and S. R. Yeaple, Multinational Firms and the Structure of International Trade, vol. 4, no. 8380. 2014.

[16] Y. Dai, "Business Cycle Synchronization in Asia: The Role of Financial and Trade Linkages," ADB Work. Pap. Reg. Econ. Integr., no. 139, 2014. 